\section{Policy entrepreneurs and problem framing: The case of climate change}

\section{Michael Mintrom}

Monash University, Australia

\section{Joannah Luetjens}

Utrecht University, The Netherlands
Environment and Planning C: Politics and Space

2017, Vol. 35(8) 1362-1377

(C) The Author(s) 2017

Reprints and permissions: sagepub.co.uk/journalsPermissions.nav DOI: 10.1 I 77/23996544I7708440 journals.sagepub.com/home/epc

@SAGE

\begin{abstract}
Policy entrepreneurs are energetic actors who work with others in and around policymaking venues to promote significant policy change. After several decades of study, we know a lot about what policy entrepreneurs do, and how to assess their effectiveness in given policymaking contexts. Here, we review common practices of policy entrepreneurs, emphasising their problem framing activities and their role in catalysing large-scale behavioural change related to climate change. We then review what policy entrepreneurs operating in various locations and at different levels of government have begun doing to tackle the climate change challenge. Like others, we contend that policy entrepreneurs will play a vital role in future efforts to address climate change. We conclude by discussing opportunities for new research on policy entrepreneurship, policymaking processes and the diffusion of policy innovations relating to climate change.
\end{abstract}

\title{
Keywords
}

Climate change, climate governance, policy entrepreneurs, policy innovation, polycentric governance

Mitigating greenhouse gas emissions and adapting to climate change represent the most fundamental societal challenges of our age. Scientific evidence confirms the earth has warmed almost $1{ }^{\circ} \mathrm{C}$ in the last 100 years due to human development activities (IPCC, 2007, 2014). These activities include increasing emissions of carbon dioxide and other greenhouse gases since the beginning of the industrial revolution. Projections for future warming due to human activity range from 1 to $6^{\circ} \mathrm{C}$ (Brysse et al., 2013). Mitigation remains a vital focus of the United Nations Framework Convention on Climate Change (UNFCCC) and the associated negotiation processes. Attention is now also being paid to adaption strategies (Hoffmann, 2011).

\section{Corresponding author:}

Michael Mintrom, ANZSOG, PO Box 230, Carlton South, Victoria 3053, Australia.

Email: m.mintrom@anzsog.edu.au 
Extensive efforts spanning decades and on a truly global scale are now required to effectively address climate change. The situation prompts many research questions. We ask: What political work is required to drive the behavioural changes needed to address climate change? To develop our answer, we focus on the work of policy entrepreneurs. We define policy entrepreneurs as energetic actors who work with others in and around policymaking venues to promote significant policy change (Mintrom and Norman, 2009). Through their political skills and their coordination efforts, these actors have the potential to promote effective responses to climate change at multiple organisational and political levels - international, national, regional, local, public and private.

After several decades of study, we know a lot about what policy entrepreneurs do, and how to assess their effectiveness in given policymaking contexts (Aflaki et al., 2015; Brouwer and Biermann, 2011; Mintrom and Norman, 2009; Schneider and Teske, 1992). Among other things, policy entrepreneurs are adept at generating, brokering and disseminating ideas through lobbying, collaboration and networking activities (Huitema and Meijerink, 2009, 2010; Roberts and King, 1991; Taylor et al., 2011). They display high levels of social acuity in their ability to understand and scan their operating environment to effect policy change (Mintrom, 2000).

In what follows, we first characterise the climate change challenge as a problem of the commons. We then review what we know about the work of policy entrepreneurs. To date, some attention has been paid to how policy entrepreneurs have promoted governmental and non-governmental responses to climate change. However, major knowledge gaps remain. In reviewing the work of policy entrepreneurs, we emphasise their problem-framing activities and why these are crucial precursors to other efforts to drive policy change. We also discuss how policy entrepreneurs can support behavioural change across various sectors of society and policy diffusion among government jurisdictions. Applying the notion of polycentricity (Ostrom, 1999), we note how multiple actions by many political actors in many different settings can scale up efforts to address climate change. Following this theoretical discussion, we present two illustrative case studies that highlight what policy entrepreneurs in different locations and at different institutional levels have started doing to tackle the climate change challenge. In our subsequent discussion, we pay close attention to the potential for microlevel actions of policy entrepreneurs to result in macro-level change. This is a matter worthy of further research, especially by those studying the dynamics of public and private responses to climate change.

\section{The climate change challenge}

Climate change is a classic example of what Hardin (1968) termed 'The Tragedy of the Commons.' Hardin described all natural resources as the commons - land, water, air, and the life they sustain. In his conceptualisation, the best strategy for individual rational actors is always to exploit a common resource, even when many actors doing so can degrade that resource. In the unrestricted commons, individuals never face incentives to restrain their own usage. However, Hardin noted that attitudes towards specific commons change as they are over-exploited. For example, while economic incentives for behavioural change do not emerge, moral sentiments can serve to change attitudes towards those who continue past practices with impunity.

Climate change has arisen because pursuit of economic development has necessitated ever-increasing carbon emissions from power plants, industrial facilities, public and private transportation, and deforestation. The cumulative effect has been over-use of the atmosphere for dissipation of airborne emissions. More and more countries, using the same 
approaches, have pursued those goals. In the process, no country has faced incentives to self-limit its atmospheric pollution. The collective sum of that pollution has reached a scale where its effects on global warming can be observed. Therein lies the tragedy. Nations have become locked in a system where pursuit of economic advancement has compelled all to increase their carbon emissions without limit. The atmosphere's capacity for carrying those emissions is limited.

The climate change challenge is potentially unwieldy. The economic incentives faced by all countries - as well as sub-jurisdictions within them - encourage actions that contribute to further global warming. What can be done to address climate change? A common view is that problems of a global nature call for a global response. In that view, the most effective means to address climate change involves the creation of an international treaty binding all states to well-specified emissions targets, with close monitoring of compliance and serious penalties for breaches. On that front, the Conference of Parties in Paris held in 2015 represents the most successful attempt so far to address a global problem with a global response.

During the Paris Conference of Parties (COP21), representatives of more than 180 countries producing more than $90 \%$ of global emissions developed a common framework for addressing climate change. The Paris Agreement blended top-down rules, to promote accountability and ambition, with bottom-up flexibility, to achieve broad participation (Rayner, 2010; Victor, 2016). It is an enduring, legally binding treaty containing emission reduction commitments from 187 countries starting in 2020. Alongside the formal agreements, countries, regions, cities, investors, and companies made a large number of commitments for additional action to reduce emissions and increase resilience. The Paris Agreement represented a huge step towards addressing climate change. That said, each signatory's pledges were self-determined, often vague, and dependent on the political will of future world leaders. Extensive work is required to achieve the agreed emissions reduction target. That work will need to occur at every level of society, from the local to the global.

Regarding the climate change challenge, Ostrom (2014) stated: 'It is important that we recognize that devising policies related to complex environmental processes is a grand challenge and that reliance on one scale to solve these problems is naive' (pp. 115-116). In Ostrom's view, an effective response to climate change requires action at many levels of governance. While acknowledging the importance of global efforts, Ostrom drew an analogy between meeting the climate challenge and the well-studied delivery of public goods in local contexts - like water supply and police services. In so doing, Ostrom touted the potential benefits of self-consciously adopting 'a polycentric approach to climate change in order to gain the benefits at multiple scales' (p. 119). Polycentricity refers to 'a social system of many decision centers having limited and autonomous prerogatives and operating under an overarching set of rules' (Aligica and Tarko, 2012: 237). The advantage of a polycentric approach is that it encourages experimental efforts at multiple levels (Ostrom, 2014).

Our interest lies in understanding the work of policy entrepreneurs who seek to address the climate change challenge at different levels of governance. In this regard, Elinor Ostrom's claim that the challenge must be met through a polycentric approach is of fundamental significance. That is because the theory of polycentric governance explicitly acknowledges the importance of entrepreneurial individuals as catalysts for broader systems change. 'Different complex systems have weak and strong points. The challenge is how to bring the strong points from one area into another in order to counter the weak points' (Aligica and Tarko, 2012: 260). Entrepreneurial individuals seek to do precisely that, both in market settings and in policy spaces. The phenomenon has been carefully theorised and has received growing empirical support (see, e.g. Mintrom, 2000; Mintrom and Norman, 2009; Olson, 1965; Ostrom, 1965; Schneider et al., 1995). We next discuss the work of policy 
entrepreneurs. In so doing, we seek to improve understanding of the political dynamics associated with multiple efforts to tackle the climate change challenge.

\section{The work of policy entrepreneurs}

In his pioneering description, Kingdon (1984/2011) noted that policy entrepreneurs ' . . .could be in or out of government, in elected or appointed positions, in interest groups or research organisations. But their defining characteristic, much as in the case of a business entrepreneur, is their willingness to invest their resources - time, energy, reputation, and sometimes money - in the hope of a future return' (p. 122). Discussions of policy entrepreneurship have evolved over time, from instances where the term was used as a loose metaphor, to more sophisticated treatments (see e.g. Huitema and Meijerink, 2010; Mintrom, 2000; Schneider and Teske, 1992).

Policy entrepreneurs seize opportunities presented by changing broader conditions. In the process, they also create new opportunities and mobilise others in support of their proposed policy innovations. For policy entrepreneurs to attain success, the policy innovations they promote must be viewed as workable. This requires amassing relevant evidence and presenting it in ways that can convince an appropriately powerful coalition of supporters to back the proposed changes. Policy innovation, then, is about more than simply coming up with good ideas. Policy innovation consists of initiation, diffusion, and the evaluation of effects that such innovations actually create (Jordan and Huitema, 2014). These challenges are central to the work of policy entrepreneurs. It is their willingness to use their positions for leverage and for aligning problems and solutions that increase the likelihood of policy change (Mintrom and Norman, 2009). The ability of policy entrepreneurs to promote policy innovation also depends on their skill at identifying relevant competencies, developing them and effectively deploying them (Considine et al., 2009; Koch and Hauknes, 2005; Meijerink and Huitema, 2010).

Improved theorisation of policy entrepreneurship has become possible through efforts to study policy entrepreneurs in context (Huitema and Meijerink, 2009, 2010; Mintrom, 1997, 2000, 2013; Mintrom et al., 2014). In this approach, attention is paid simultaneously to contextual factors, to individual actions within those contexts, and to how contexts shape actions. We now know that just because specific policy entrepreneurs effectively deploy a range of advocacy skills, this alone cannot ensure that they will attain the policy changes they are pursuing. Collectively, this recent empirical work offers a more nuanced appreciation of dynamic policy change than the view that it is driven mostly by a few well-placed policy heroes with time on their side. Here, we focus on two under-studied aspects of the work of policy entrepreneurs: their problem framing efforts and their efforts to scale up policy change. These aspects of policy entrepreneurship are highly relevant to efforts to address climate change.

\section{Problem framing}

Problem framing is a crucial precursor to other efforts to drive policy change. Policy entrepreneurs must give it close attention. Traditionally, problem framing has been thought to involve, among other things, presenting evidence in ways that suggest a crisis is at hand (Carson, 1962; Nelson, 1984; Rabe, 2004; Stone, 1997), finding ways to highlight failure of current policy settings (Baumgartner and Jones, 1993; Henig, 2008), and drawing support from actors beyond the immediate scope of the problem (Levin and Sanger, 1994; Roberts and King, 1991; Schattschneider, 1960). In a recent discussion of climate change, 
Keohane (2015) introduced and discussed five 'policy frames,' indicating how each draws attention to particular aspects of the problem.

While we accept traditional descriptions of the strategic practices and intentions associated with problem framing noted in the Introduction of this Special Issue (Boasson and Huitema, 2017), we see value in exploring the predispositions that increase the likelihood that framing will engender intended outcomes. In doing so, we take our cue from Dewulf and Bouwen's (2012) emphasis on the 'interactional' nature of framing. In this interpretation, 'framing works through arranging and rearranging the elements of an issue such that its meaning is altered, a process that involves selecting certain issue elements as part of the frame while leaving out others and putting particular issue elements into focus while leaving only a marginal role for other elements' (p. 170). This interpretation of framing would cast policy entrepreneurs as active conversationalists who construct the meaning of situations through discussion with others, rather than as architects who establish frames in advance of discussion, with the intention of using rhetorical skills to persuade others to adopt them as is.

The notion that problem framing is interactional is well-aligned with what policy entrepreneurs do. Of course they approach problems with particular preferences concerning the policy solutions that could be adopted to address them. However, through interacting with others, they develop new understandings of problems and the solutions that would most effectively address them. This portrayal of how connections are drawn between problems and solutions opens the possibility that technically superior solutions might be passed over in preference for politically superior ones. Indeed, almost always it is better to gain acceptance of an 'inferior' policy proposal over no policy change. That is because - as a huge amount of evidence verifies - incremental steps in policymaking often establish platforms for subsequent policy reforms that can eventually lead to more desirable outcomes (Derthick and Quirk, 1985; Mintrom, 2000; Patterson, 2000). In the cut-andthrust of politics, 'interactional' framing can be far more pragmatic than any other kind. Shortly, we will discuss examples of how policy entrepreneurs have made effective use of problem framing to promote specific efforts to address climate change.

\section{Catalysing large scale behavioural change}

Policymaking takes place in many venues that differ dramatically in terms of their jurisdictional reach and broader significance. For those interested in the dynamics of major policy change, cases of policy entrepreneurs who have influence beyond their primary jurisdiction are of particular interest. Policy innovations may diffuse horizontally or vertically or through a combination of both dynamics. Important initial efforts have been made to explain policy innovation diffusion processes and incorporate understandings of policy entrepreneurship within them (Mintrom, 1997; Shipan and Volden, 2006). However, further investigation is needed. Addressing climate change offers a substantively important, polycentric case where exploration of the dynamics of policy entrepreneurship and policy innovation diffusion can be usefully explored.

There are limits to the geographical influence any particular policy entrepreneur might enjoy. Given language and cultural barriers, nobody can exhibit high levels of social acuity across all social, political, and cultural contexts. Just as rationality is bounded (Simon, 1947/ 1997), social acuity is bounded. Consequently, policy entrepreneurs must always operate in particular socio-political spaces, the boundaries of which they cannot easily alter nor traverse. Sound evidence points to the very different domestic political and policy contexts in which policy entrepreneurs must operate. These contexts are shaped, among other things, by political regime type (democratic versus nondemocratic, and so on), political institutions 
(federalism, division of powers, veto points in the legislative process, electoral systems, and so on), the composition and power of interest groups, prevailing ideologies and discourses, and historical legacies (Christoff and Eckersley, 2011).

Policy entrepreneurs must always be aware of how policy changes might be achieved in the face of specific political institutions, interests, and ideologies. Additionally, if they seek to have broad impact, they must consider issues of scale. For those seeking to address climate change, key questions include: How do specific, local efforts to reduce greenhouse gas emissions measure up against global targets? How might local efforts be replicated elsewhere, or be improved in light of knowledge concerning policy initiatives in other contexts? How can entrepreneurial activities be pursued where policy actions are required at multiple institutional levels? The greater the attention policy entrepreneurs pay to effective scaling of strategies to mitigate or adapt to climate change, the more they serve as catalysts and supporters of global-level change. Policy entrepreneurs who combine high levels of skills with broad ambition place themselves in the realm where 'creative destruction' could be ignited in the policymaking space. Older policy settings may be put aside as policy innovations are adopted, and cross-jurisdictional learning opens the way for dynamic change in the form of policy innovation diffusion.

Viewing the climate change challenge as occurring in a polycentric space, numerous opportunities exist for energetic actors to operate as policy entrepreneurs in support of actions to address it (Ostrom, 2014; Termeer et al., 2011). Some such actions have already been carefully researched and reported. For example, Boasson and Wettestad (2014) assessed policy entrepreneurship relating to carbon sequestration in the European Union. They showed how policy entrepreneurs with skills in problem framing created windows of opportunity for subsequent policy entrepreneurs to further advance change processes. That analysis usefully distinguished between the time-frames within which different policy entrepreneurs work. Those who softened up the political context the authors referred to as 'tortoises.' Those who took advantage of improved contexts are referred to as issuespecific 'carpe diemers.' In another example of recent work looking at the differential actions of policy entrepreneurs in the climate change space, Hermansen (2015) studied policy entrepreneurship surrounding the development of Norway's International Climate and Forest Initiative. He reported how two Norwegian organisations combined one's interest in rainforest preservation with the other's interest in mitigating climate change. In the process, they created a window of opportunity for subsequent legislative advocacy that saw Norway contribute significant resources to the worldwide effort to reduce emissions from deforestation and forest degradation (REDD+).

In what follows, we explore the political work required to drive the behavioural changes needed to address climate change. We present two cases of how policy entrepreneurs have been working to address such challenges across the public and private spheres. Following reflection on these cases and how they demonstrate effective problem framing and scaling up of influence efforts, we then enter a more speculative concluding discussion, motivated by the question: What kinds of policy entrepreneurship are we likely to see emerge in the coming years to further meet the climate change challenge?

\section{Policy entrepreneurs and climate change: Two cases}

Over the past 15 years, many efforts have emerged, across the public, private and non-profit sectors, to tackle the challenges of climate change (see, for example, Maor, 2017). Potential cases for discussion here had to demonstrate their ability to contribute to the resolution of the analytical challenges posed by Jordan et al. (2015), namely initiation, distribution, and 
performance. As such, our case selection followed three criteria. First, potential cases had to highlight policy entrepreneurship that exhibited explicit interactional problem framing efforts. We consider this as initiation. Second, potential cases had to demonstrate ambition on the part of the policy entrepreneur to secure broad and positive systemchanging impacts across different spheres of influence. We consider this as distribution. Third, potential cases had to contain plausible evidence of success on the part of the policy entrepreneurs in their agenda setting and policy change efforts. We consider this as a starting point for assessing performance.

Our cases also offer further support to Ostrom's (2014) call for re-examination of the claim that 'solutions to global change must be global in scale' (p. 98). A polycentric approach for coping with climate change recognises that multiple efforts across multiple locations and involving multiple levels of government are necessary. We are aware that policy entrepreneurs often encounter failure and that it is possible to derive valuable lessons from failure (see, e.g. Mintrom, 2014). As highlighted in the Introduction to this Special Issue (Boasson and Huitema, 2017), future studies of policy entrepreneurs seeking to address climate change would benefit from analysis of both success and failure. For current purposes, dwelling on failure would restrict our ability to explore the catalysing, "creative destruction' dynamic of policy entrepreneurship - a dynamic of high relevance to addressing climate change as well as to the further theorisation of policy entrepreneurship.

Our first case, the C40 Cities Climate Leadership Group (C40), illustrates how mayors of large cities sought to take initiative and lead change where nation-states were perceived as failing to do so. Our second case, the Carbon Disclosure Project (CDP) began as a nongovernmental initiative that catalysed climate change mitigation and adaptation efforts on the part of many corporations, governments and policymakers. The insights from these cases suggest that it is important to build adaptive capacity by evolving technologies, institutions and management practices to address and manage the changing climate. This view is supported by the emergence of the partnership that formed between C40 and CDP in 2010. Recognising their limitations, both organisations sought to strengthen their resolve by leveraging off the multiple jurisdiction-spanning networks that each organisation had successfully developed individually. Those scaling-up actions are consistent both with theory-driven predictions and previous empirical observations of what policy entrepreneurs do in polycentric governance systems (Jordan et al., 2015).

Case 1: The C40 Cities Climate Leadership Group (2005-) C40 is composed of mayors of the world's megacities committed to reducing greenhouse gas emissions in their jurisdictions. The group was originally convened by Ken Livingstone, who we consider the key policy entrepreneur in this case. Without his initial efforts and on-going involvement, the group may never have formed. Livingstone drew many other highly able city leaders around him who, in their turn, have acted as policy entrepreneurs.

As mayor of London from 2000 to 2008, Ken Livingstone aimed to position London as a leading global city. This is evidenced by the release of The London Plan, officially launched in 2004. The Plan, focusing on the integration of urban governance, contributed and solidified Livingstone's desire to make London a green city (Acuto, 2013a). Under his Climate Change Action Plan, he called for London to get $25 \%$ of its power from more efficient local sources and reduce carbon emissions by $60 \%$ within 20 years. He pledged significant resources to these efforts. Livingstone has said climate change, and how to avert it, consumes him. It informed his mayoral decisions on transport, social housing and new business developments.

The origins of C40 date back to 2005, when Ken Livingstone hosted the World Cities Leadership and Climate Summit in London (Rosenzweig et al., 2010). Representatives from 18 megacities were invited to London to discuss actions they could take to reduce greenhouse 
gas emissions from their cities. Livingstone's fundamental problem framing act involved representing cities - rather than nation-states - as central agents in the response to climate change. This framing is significant. Until this point, governments of nation-states were expected to take the lead on addressing climate change. By framing climate change as a fundamental issue facing urban populations, cities were able to assert themselves as key players (Betsill and Bulkeley, 2007). As the symbolic 'voice of London,' Livingstone emphasised that cities consume over two-thirds of the world's energy and account for more than $70 \%$ of global carbon dioxide emissions. Cities are also extremely vulnerable to climate change, as $75 \%$ of urban settlements are at risk from sea-level rise (McGranahan et al., 2007). Members of the group subsequently came to frame the increasing pressures that cities are facing - population growth, planning policy, infrastructure provision, and so on as presenting major opportunities to lower their carbon footprint through more efficient infrastructure and planning (Kern and Bulkeley, 2009; Rabe, 2004; Victor et al., 2005).

In establishing C40, Livingstone argued that cities should take 'practical action on the ground' and not fuss with brand new approaches to sustainability (Acuto, 2013b). Claiming that there was no time for 'more studies or surveys,' Livingstone sought to learn from the actions of cities around the world that were using innovative means to reduce their emissions. By focusing on building requirements, insulation, solid waste, energy efficiency, traffic congestion and water systems, Livingstone suggested the group could have an immediate impact of greenhouse gas emissions. He recognised that pooling existing knowledge and resources was essential to approaching climate issues (Lee and van de Meene, 2012). The 2005 Summit showcased these cities' centrality and role in responding to climate change whilst simultaneously underscoring their central role as key hubs for implementation of population, business and environmental policies. By presenting their agency on this issue as both source and solution for climate change, they argued for more extensive interconnection of an already established capacity.

Upon conclusion of the 2005 Summit, the eighteen cities formed the C20 Partnership and issued a joint Communique that committed to holding a follow up meeting to measure progress and to report back to the United Nations. Negotiating the establishment of this group initially meant the formalisation of pre-existing ties among major cities. The partnership quickly grew to comprise 40 members and under Livingstone's leadership, the group installed a London-based Secretariat, appointed a Steering Committee, and introduced an issue-specific workshop program.

In 2006, the group partnered with the William J. Clinton Foundation to use the newlycreated Clinton Climate Initiative (CCI) to implement C40 initiatives. This partnership resulted in a set of collaborative sub-networks, organised and overseen by CCI. CCI also developed a database of member city jurisdictional capacities, authority and actions to create a platform for inter-city sharing of ideas, information and data. Through partnerships and collaboration, C40 increased its ability to leverage the potential for inter-city transfer of knowledge, expertise and experience, and to empower local officials and citizens to drive local changes (Schreurs, 2008).

C40's reach and influence has continued to grow. In recent times, it has formed partnerships with the World Bank, Bloomberg Philanthropies, World Resources Institute (WRI) and Local Governments for Sustainability (ICLEI). C40's collaborations with WRI and ICLEI have produced a global guide for accounting and reporting community-scale greenhouse gas emissions that can be used across multiple platforms. This guide is the first internationally accepted framework for city-level greenhouse gas inventories.

Case 2: The Carbon Disclosure Project (2000-) The CDP is an independent, non-profit organisation established in 2000 that seeks to tackle climate change by moving mitigation 
efforts and energy efficiency into mainstream business thinking. The project is built around the collection and reporting of information. It has been motivated by the belief that documenting behaviour is a first step towards promoting behavioural change. Understood in this way, the CDP follows the logic of organisational report cards (Gormley and Weimer, 1999). Collecting and reporting information for the purpose of driving behavioural change is an increasingly popular tool across an array of public policy domains and also among nongovernmental entities. The actions of the CDP, while initially aimed at changing the behaviour of businesses, have subsequently influenced governmental actions.

By disclosing emissions, CDP believes companies can better understand how to protect themselves from the impacts of climate change and become more energy efficient. Founded by Paul Dickinson and Tessa Tennant, CDP encourages organisations to disclose their greenhouse gas emissions and climate change strategies by responding to voluntary questionnaires. We argue that the actions taken by Dickinson and Tennant clearly distinguish them as policy entrepreneurs. They framed climate change as a problem that businesses should care about, they built effective, non-coercive partnerships with others, and in creating a significant disclosure database, they displayed leadership by example. Taking such actions and effectively engaging with potentially hostile business interests called for significant levels of social acuity. The demonstration effects of their actions have influenced how government policymakers now seek to address climate change.

Tessa Tennant, co-founder and first Chair of CDP, has devoted her career to innovation in financial services for sustainability. In 1998, while working at NPI Global Care, Tennant proposed a carbon dioxide benchmarking scheme, aiming to make the carbon dioxide intensity of companies publicly available and of use in guiding investment decisions. After several years of discussing the idea with others and refining it, Tennant established CDP to implement it.

In 2003, CDP issued its first questionnaire asking companies to disclose their past and future carbon emissions. Recognising that individual governments may be reluctant to develop national limits on emissions, the CDP sought to initially sidestep national interests by focusing on individual corporations. Disclosure is intended to trigger behavioural change among firms, spurring innovation and the consideration of environmental risks (Pattberg, 2012). Some corporations are responsible for more emissions than individual nation states. Founded primarily on the assumption that environmental policy can and should be directed through responsible investment practices, CDP seeks to uncover the 'carbon truth' of the private sector (Andrew and Cortese, 2011). By framing climate change as a business risk, Tennant, Dickinson, and others at CDP recognised the scope to reduce energy usage and greenhouse gas emissions by adopting energy efficiency methods and business planning.

CDP's first request for information received approximately 235 responses. In 2016, the CDP received carbon data from over 5500 companies in over 90 countries. The vast majority of Global 500 corporations (82\%) report their greenhouse gas emissions and climate change strategies to the CDP (CDP, 2014). Similarly, over 827 investors representing over US\$100 trillion in assets have now signed up to support the CDP's disclosure efforts, which has helped the initiative become the world's largest database for climate change risk information. As a consequence of this wide constituency of support, over 4000 publicly listed companies have produced reports on climate change risk since CDP established its survey.

CDP pursued several discursive strategies to help institutionalise carbon disclosure as a routine practice - and something both businesses and governments should care about. They framed carbon disclosure as an extension of carbon trading, capitalising on the broad support that this market-based mechanism had already achieved (Kolk et al., 2008). Tennant and Dickinson displayed particularly high levels of social acuity in 
understanding the influence that institutional investors have on the private sector. Graham et al. (2005) note institutional investors are extremely important in determining and setting the firm's stock price. This is a key consideration for chief financial officers.

In 2010, building on its carbon disclosure program for the private sector, CDP launched its Cities program in partnership with the $\mathrm{C} 40$. This program, which is explicitly designed to prompt policy changes to support reductions in the emission of greenhouse gases, provides a platform for cities worldwide to report on their greenhouse gas emissions and climate-related policy initiatives. Since 2010, CDP has worked with over 533 cities to manage 2 gigatonnes of greenhouse gas emissions. Recognising the crucial link between cities, industry and economic growth, CDP's partnership with C40 enables the necessary tools, best practices, and support mechanisms to assess the emissions reduction impact of city-level public policy changes.

CDP has displayed strategic skill in presenting the project in ways that appeal to multiple stakeholders (Knox-Hayes and Levy, 2011). For business audiences, CDP emphasised the financial benefits from energy savings and good public relations, and the voluntary nature of disclosure, which provides flexible implementation with little legal exposure. Similarly, investors were enticed by the claim that carbon disclosure would assist in valuing financial assets by revealing the degree of climate risk. To appeal to NGOs and multilateral organisations such as UNEP, the emphasis was placed on improving corporate accountability and creating more inclusive and transparent governance mechanisms. To maximise its effectiveness and reach, CDP has worked with different organisations like the Global Reporting Initiative to ensure alignment within their respective reporting frameworks. CDP have invoked the broader 'win-win' frame of corporate social responsibility and reporting, in asserting that better environmental performance would lead to better financial performance. These discursive strategies provided the basis for an organisational strategy to build an alliance with environmental groups, firms and investors (Kolk et al., 2008).

While CDP has become a highly visible and prominent entity of private environmental coordination and governance, the impact of CDP on efforts to mitigate carbon emissions is not clear. Paul Dickinson has argued that the success of the organisation is real but unquantifiable: 'I'm quite confident that the CDP approach has had a real impact on business... but what it is we can't quantify yet even as more and more investors jump on board. They're convinced they have to be here' (MacLeod and Park, 2011). What CDP does demonstrate, however, is that environmental issues are now becoming issues for strategic engagement, rather than as matters of legal compliance (Howard-Grenville and Hoffman, 2003).

Following the release of IPCC's Fifth Assessment Report in early 2014, CDP partnered with the WRI and the World Wide Fund for Nature (WWF) to develop a new target-setting methodology to provide companies with a useful sector-specific tool to align their greenhouse gas targets with the IPCC's decarbonisation pathway that would keep global temperature rise below $2{ }^{\circ} \mathrm{C}$. This 'Mind the Science, Mind the Gap' initiative seeks to raise CDP's ambitions of corporate target-setting levels and drive bolder business solutions. It is expected that by 2018, more than 100 multi-national companies will be setting targets based on the proposed methods and annually reporting their results to CDP.

\section{Discussion}

The two illustrative cases presented above highlight policy entrepreneurs who engaged in interactional framing to influence responses to climate change. In both cases, the policy entrepreneurs took actions that would reduce greenhouse gas emissions without reliance 
upon a singular global accord. In that sense, their actions lend further support to Ostrom's (2014) contention that the climate change challenge is most appropriately addressed by polycentric rather than monocentric governance arrangements. Indeed, the learning through action and the efforts to share experience across locations illustrated in both our cases are consistent with expectations derived from studies of entrepreneurial behaviour within polycentric settings. They are also indicative of the efforts actors can make in initiating policy solutions and promoting the diffusion of innovation.

For the C40 Cities Climate Leadership Group, the initial framing move was to suggest that cities are fundamental players in emission reduction and that, by learning from each other, significant progress could be made. The initial 2005 Summit provided a mechanism for communities to 'think global, act local.' C40 membership is voluntary and non-binding. Its aim was to highlight capacity building and information sharing, both of which are envisaged in Ostrom's conceptualisation of polycentricity (Jordan et al., 2015). The CDP utilised the frame that what gets measured gets managed and capitalised on the broad support of established market-based mechanisms to pursue its agenda. CDP emphasised the importance of achieving first-mover advantage and opted to use competition, or perceived competition, as a means to drive climate change efforts. The significance of these cases, in terms of policy entrepreneurship, is the catalysing effects these actors had. Initiatives that began in closely circumscribed contexts were effectively scaled up and diffused, producing major, international impacts. Livingstone, in the case of C40 Cities, was able to use his positional power and influence to formally connect major cities around the world in a way that had never been done before. The emphasis on learning and achieving a common goal was critical to this vision, and the pursuit of polycentric governance more broadly. It is unlikely that it would have been achieved with such vigour if the founder lacked Livingstone's ambition.

There is evidence to suggest that private companies have understood the implications of man-made carbon emissions since as early as the 1970s (Dunlap and McCright, 2011). CDP has been part of the effort to facilitate a shift in the private sector regarding environmental protection and corporate responsibility. The initiative has gained steady ground since its establishment, spurring more major corporations to disclose their emissions. While the effect of disclosure on the overall effort to mitigate emissions is unclear, it represents an important piece of the puzzle on how a coordinated response to climate change may arise. The case further indicates how policy entrepreneurs can catalyse efforts by others.

In each case discussed here, the novel problem frame emerged after lengthy efforts to appreciate specific venues within which well-chosen policy changes and related behavioural changes could generate valued outcomes. As we have seen, policy entrepreneurs do not necessarily need one single framing or base for their actions. The workable frames always emerged through discursive interactions. These policy entrepreneurs constructed their problem frames through engagement in specific contexts and by being alert to opportunities. Once those frames were established, the same social acuity that contributed to their development allowed the various policy entrepreneurs - in their various ways - to subsequently build appropriate teams, networks, and coalitions, and provide leadership by example. Through their actions, they encouraged similar actions on the part of others. They catalysed change processes that could not possibly have occurred without many people bringing their enthusiasm and energy to the cause.

Policy entrepreneurs need not contribute something completely new - indeed an existing idea introduced into a new context may suffice (Rogers, 1962/1995). The hallmark and innovation of policy entrepreneurship is the finding and combining of ideas and meanings from a diversity of contexts and actors. In the cases of C40 and CDP, the originating policy entrepreneurs have seen their initial innovations scaled up in highly significant ways. The 
actions noted here have changed how people think about climate change and have influenced how they are seeking to tackle it. The scope of influence has been significant.

\section{Conclusion}

We have discussed the climate change challenge and the potential for policy entrepreneurs to contribute to mitigation and adaptation efforts. We acknowledge the crucial role that global treaties play in gaining general agreement on ways forward with addressing climate change. However, such contributions in themselves are insufficient to address the grand challenge of climate change. High-level agreements depend upon behavioural changes at the local level, where decisions made by individuals and small groups on a day-to-day basis directly control atmospheric emissions. Multiple efforts across multiple jurisdictions and layers of government must be pursued to reduce the emission of greenhouse gases. That effort will need to be sustained for decades to come.

In discussing the actions of policy entrepreneurs, we have focused specifically on the political work required to frame problems and how this can contribute to the scaling up of policy innovations. In concluding our discussion, we now ask: What kinds of policy entrepreneurship are we likely to see emerge in the coming years to further meet the climate change challenge? While policy entrepreneurs at the local level will perform many crucial tasks, we also anticipate that those who will have most influence will deliberately connect what they are doing with what others are doing elsewhere. As such, we are especially interested in the potential for micro-level actions of policy entrepreneurs to result in macro-level change.

Given the enormity of the climate change challenge, much room exists for energetic actors we term policy entrepreneurs to make significant contributions in the decades ahead. We have focused on interactive problem framing because we see this as a vital item in the policy entrepreneurship toolkit. Plenty of evidence suggests that entrepreneurs in all areas of social and economic life gain insights about potentially workable solutions to problems through their close engagement with others. Policy entrepreneurs discover what others are looking for and shape their proposals for policy innovation and change accordingly. We anticipate that a lot of creative problem framing will be required in the years ahead as policy entrepreneurs in many locations work to promote effective means of mitigating and adapting to climate change.

Beyond problem framing, we have also discussed how policy entrepreneurs work to spread smart solutions to problems. We have called this scaling up. When policy entrepreneurs work with others to diffuse specific policy innovations, they can bring benefits for large numbers of people. Previous contributions to the study of policy entrepreneurs have noted how coalition building and networking efforts can support the diffusion of policy innovations. However, a lot of opportunities remain for further refining of our knowledge concerning the careful political work that supports scaling up. Like problem framing, this is an aspect of policy entrepreneurship that is subject to a lot of performance variability. Research directed at understanding when and how scaling up efforts meet with success or failure could contribute significantly to our knowledge of the dynamics of policy innovation diffusion.

We anticipate many opportunities will emerge in the coming years for comparative studies of scaling up climate change mitigation and adaptation strategies. In the best cases, research concerning policy entrepreneurship in the climate change space will contribute both to improved theorising of policy processes and to guidance for advocacy practices. We view that theory-practice nexus positively and encourage other researchers to fill some of the many gaps currently existing there. Indeed, such research has the potential to rapidly become a large, insight-rich stream of social science. 


\section{Acknowledgements}

An earlier version of this manuscript was prepared as background for a Keynote Speech at the Workshop on Entrepreneurship and Climate Governance, VU University Amsterdam, 18-19 May 2015. We wish to thank workshop participants, the Special Issue Editors Elin Lerum Boasson and Dave Huitema, the anonymous referees, as well as Jonathan Boston, Evangelia Petridou, Barry Rabe and Jacqui True for their encouragement and valuable advice as we completed the paper. Any omissions or errors are our responsibility.

\section{Declaration of conflicting interests}

The author(s) declared no potential conflicts of interest with respect to the research, authorship, and/or publication of this article.

\section{Funding}

The author(s) disclosed receipt of the following financial support for the research, authorship, and/or publication of this article: Funding source: COST Action INOGOV (IS1309 Innovations in Climate Governance: Sources, Patterns and Effects) (2014-18).

\section{References}

Acuto M (2013a) Global Cities, Governance and Diplomacy: The Urban Link. London, UK: Routledge. Acuto M (2013b) The new climate leaders? Review of International Studies 39(4): 835-857.

Aflaki IN, Petridou E and Miles L (eds) (2015) Entrepreneurship in the Polis: Understanding Political Entrepreneurship. Burlington, VT: Ashgate.

Aligica PD and Tarko V (2012) Polycentricity: From Polanyi to Ostrom, and beyond. Governance 25(2): 237-262.

Andrew J and Cortese C (2011) Accounting for climate change and the self-regulation of carbon disclosures. Accounting Forum 35: 130-138.

Baumgartner FR and Jones BD (1993) Agendas and Instability in American Politics. Chicago: University of Chicago Press.

Betsill M and Bulkeley H (2007) Looking back and thinking ahead: A decade of cities and climate change research. Local Environment 12(4): 447-456.

Boasson EL and Huitema D (2017) Climate governance entrepreneurship: Emerging findings and a new research agenda. Environment and Planning C: Politics and Space 35(8): 1343-1361.

Boasson EL and Wettestad J (2014) Policy invention and entrepreneurship: Bankrolling the burying of carbon in the EU. Global Environmental Change 29: 404-412.

Brouwer S and Biermann F (2011) Towards adaptive management: Examining the strategies of policy entrepreneurs in Dutch water management. Ecology and Society 16(4): 5-23.

Brysse K, Oreskes N, O'Reilly J, et al. (2013) Climate change prediction: Erring on the side of least drama? Global Environmental Change 23(1): 327-337.

Carson R (1962) Silent Spring. New York: Houghton Mifflin.

CDP (2014) CDP S\&P 500 Climate Change Report 2014. Available at: www.cdp.net/CDP-SP500leaders-report-2014.pdf (accessed 15 December 2015).

Christoff P and Eckersley R (2011) Comparing state responses. In: Dryzek JS, Norgaard RB and Schlosberg D (eds) The Oxford Handbook of Climate Change and Society. New York: Oxford University Press, pp. 431-448.

Considine M, Lewis J and Alexander D (2009) Networks, Innovation and Public Policy: Politicians, Bureaucrats and the Pathways to Change Inside Government. New York: Palgrave Macmillan.

Derthick M and Quirk PJ (1985) The Politics of Deregulation. Washington, DC: Brookings Institution.

Dewulf A and Bouwen R (2012) Issue framing in conversations for change: Discursive interaction strategies for 'doing differences'. The Journal of Applied Behavioral Science 48(2): 168-193. 
Dunlap RE and McCright AM (2011) Organized climate change denial. In: Dryzek JS, Norgaard RB and Schlosberg D (eds) The Oxford Handbook of Climate Change and Society. New York: Oxford University Press, pp. 144-160.

Gormley WT and Weimer DL (1999) Organizational Report Cards. Cambridge, MA: Harvard University Press.

Graham JR, Harvey CR and Rajgopal S (2005) The economic implications of corporate financial reporting. Journal of Accounting and Economics 40(1-3): 3-73.

Hardin G (1968) The tragedy of the commons. Science 162(3859): 1243-1248.

Henig JR (2008) Spin Cycle: How Research is Used in Policy Debates: The Case of Charter Schools. New York: Russell Sage Foundation.

Hermansen EA (2015) Policy window entrepreneurship: The backstage of the world's largest REDD+ initiative. Environmental Politics 24(6): 932-950.

Hoffmann MJ (2011) Climate Governance at the Crossroads: Experimenting with a Global Response after Kyoto. New York: Oxford University Press.

Howard-Grenville JA and Hoffman JA (2003) The importance of cultural framing to the success of social initiatives in business. Academy of Management Executive 17(2): 70-84.

Huitema D and Meijerink S (2009) Water Policy Entrepreneurs. Cheltenham: Edward Elgar Publishing.

Huitema D and Meijerink S (2010) Realizing water transitions: The role of policy entrepreneurs in water policy change. Ecology and Society 15(2): 26.

Intergovernmental Panel on Climate Change (IPCC) (2007) Summary for Policymakers. In: Solomon S, et al. (eds) Climate Change 2007: The Physical Science Basis. Contribution of Working Group I to the Fourth Assessment Report of the Intergovernmental Panel on Climate Change. Cambridge and New York: Cambridge University Press.

Intergovernmental Panel on Climate Change (IPCC) (2014) Summary for Policymakers. In: Edenhofer O, et al. (eds) Climate Change 2014: Mitigation of Climate Change. Contribution of Working Group III to the Fifth Assessment Report on the Intergovernmental Panel on Climate Change. Cambridge and New York: Cambridge University Press.

Jordan AJ and Huitema D (2014) Policy innovation in a changing climate: Sources, patterns and effects. Global Environmental Change 29: 387-394.

Jordan AJ, Huitema D, Hilden M, et al. (2015) Emergence of polycentric climate governance and its future prospects. Nature Climate Change 5(11): 977-982.

Keohane RO (2015) The global politics of climate change: Challenge for political science. PS: Political Science \& Politics 48(1): 19-26.

Kern K and Bulkeley H (2009) Cities, Europeanization and multi-level governance: Governing climate change through transnational municipal networks. JCMS: Journal of Common Market Studies 47(2): 309-332.

Kingdon JW (2011) Agendas, Alternatives, and Public Policies. Updated 2nd ed. Boston: Longman.

Knox-Hayes J and Levy DL (2011) The politics of carbon disclosure as climate governance. Strategic Organization 9(1): 1-9.

Koch P and Hauknes J (2005) On Innovation in the Public Sector - Today and Beyond. PUBLIN Project on Innovation in the Public Sector, Report no. D20. Oslo: Nifu Step.

Kolk A, Levy DL and Pinkse J (2008) Corporate responses in an emerging climate regime: The institutionalization and commensuration of carbon disclosure. European Accounting Review 17(4): 719-745.

Lee T and van de Meene S (2012) Who teaches and who learns? Policy learning through the C40 cities climate network. Policy Sciences 45(3): 199-220.

Levin MA and Sanger MB (1994) Making Government Work: How Entrepreneurial Executives Turn Bright Ideas into Real Results. San Francisco: Jossey-Bass.

McGranahan G, Balk D and Anderson B (2007) The rising tide: Assessing the risks of climate change and human settlements in low elevation coastal zones. Environment and Urbanization 19(1): 17-37.

MacLeod M and Park J (2011) Financial activism and global climate change: The rise of investordriven governance networks. Global Environmental Politics 11(2): 54-74. 
Maor M (2017) Policy entrepreneurs in policy valuation processes: The case of climate governance. Environment and Planning C: Politics and Space 35(8): 1401-1417.

Meijerink S and Huitema D (2010) Policy entrepreneurs and change strategies: Lessons from sixteen case studies of water transitions around the world. Ecology and Society 15(2): 21-39.

Mintrom M (1997) Policy entrepreneurs and the diffusion of innovation. American Journal of Political Science 41: 738-770.

Mintrom M (2000) Policy Entrepreneurs and School Choice. Washington, DC: Georgetown University Press.

Mintrom M (2013) Policy entrepreneurs and controversial science: Governing human embryonic stem cell research. Journal of European Public Policy 20(3): 442-457.

Mintrom M (2014) Policy entrepreneurs and morality politics: Learning from failure and success. In: Aflaki IN, Miles L and Petridou E (eds) Entrepreneurship in the Polis: Contested Entrepreneurs and Dynamics of Change in Diverse Contexts. Farnham: Ashgate Publishing, pp. 103-118.

Mintrom M and Norman P (2009) Policy entrepreneurship and policy change. Policy Studies Journal 37(4): 649-667.

Mintrom M, Salisbury C and Luetjens J (2014) Policy entrepreneurs and promotion of Australian state knowledge economies. Australian Journal of Political Science 49(3): 423-438.

Nelson B (1984) Making an Issue of Child Abuse. Chicago: University of Chicago Press.

Olson M (1965) The Logic of Collective Action: Public Goods and the Theory of Groups. Cambridge, MA: Harvard University Press.

Ostrom E (1965) Public entrepreneurship: A case study in ground water basin management. Doctoral dissertation, University of California, Los Angeles.

Ostrom E (2014) A polycentric approach for coping with climate change. Annals of Economics and Finance 15(1): 97-134.

Ostrom V (1999) Polycentricity - Part 1. In: McGinnis M (ed.) Polycentricity and Local Public Economies. Ann Arbor: University of Michigan Press, pp. 52-74.

Pattberg P (2012) How climate change became a business risk: Analyzing nonstate agency in global climate politics. Environment and Planning C: Government and Policy 30(4): 613-626.

Patterson JT (2000) America's Struggle Against Poverty in the Twentieth Century. Cambridge, MA: Harvard University Press.

Rabe BG (2004) Statehouse and Greenhouse: The Emerging Politics of American Climate Change Policy. Washington, DC: Brookings Institution Press.

Rayner S (2010) How to eat an elephant: A bottom-up approach to climate policy. Climate Policy 10(6): 615-621.

Roberts NC and King PJ (1991) Policy entrepreneurs: Their activity structure and function in the policy process. Journal of Public Administration Research and Theory 1(2): 148-175.

Rogers EM (1962/1995) Diffusion of Innovations. 3rd ed. New York: The Free Press.

Rosenzweig C, Solecki W, Hammer SA, et al. (2010) Cities lead the way in climate-change action. Nature 467: 909-911.

Schattschneider EE (1960) The Semi-Sovereign People. Hinsdale: The Dryden Press.

Schneider M and Teske P (1992) Toward a theory of the political entrepreneur: Evidence from local government. American Political Science Review 86(3): 737-747.

Schneider M, Teske P and Mintrom M (1995) Public Entrepreneurs: Agents for Change in American Government. Princeton, NJ: Princeton University Press.

Schreurs MA (2008) From the bottom up: Local and subnational climate change politics. The Journal of Environment \& Development 17(4): 343-355.

Shipan CR and Volden C (2006) Bottom-up federalism: The diffusion of antismoking policies from US cities to states. American Journal of Political Science 50(4): 825-843.

Simon HA (1947/1997) Administrative Behavior: A Study of Decision-Making Processes in Administrative Organizations, 4th ed. New York: Free Press.

Stone D (1997) Policy Paradox: The Art of Political Decision Making. New York: W.W. Norton.

Taylor A, Cocklin C, Brown R, et al. (2011) An investigation of champion-driven leadership processes. The Leadership Quarterly 22: 412-433. 
Termeer C, Dewulf A, van Rijswick H, et al. (2011) The regional governance of climate adaptation: A framework for developing legitimate, effective, and resilient governance arrangements. Climate Law 2(2): $159-179$.

Victor DG (2016) What the framework convention on climate change teaches us about cooperation on climate change. Politics and Governance 4(3): 133-141.

Victor DG, House JC and Joy S (2005) A Madisonian approach to climate policy. Science 309: $1820-1821$.

Michael Mintrom is a professor of public sector management at Monash University with a joint appointment as an academic director at the Australia and New Zealand School of Government.

Joannah Luetjens is a doctoral fellow in the Utrecht School of Governance at Utrecht University. She was previously a research and administration officer at the Australia and New Zealand School of Government. 